\title{
A few words about the difficulties in the procedure for nullitas matrimonii and the Metropolitan Court in Bialystok
}

The author of the article after a brief reflection reminiscent the story of the Metropolitan Court in Bialystok raises issues concerning the canon proceedings. He draws attention to the common perception in the society, and especially in the media, about the concept of the "church divorce". He shows how wrong it is formulated and what negative effects entail its use. This leads in fact to identification of the canonical proceedings for annulment of the marriage with the divorce proceedings. Similarly, the author explains who is the defendant in a canonical process, so often mistakenly equated in the common sense with the accused in a criminal trial. It also indicates the important role played by a witness in the proceedings. The author warns the interested in canonical proceedings against the use of accidental legal advice and encourages these people to direct contact with the ecclesiastical courts, where one can find a friendly and professional legal advice.

Key words: canonical process, party in the canonical proceedings, witness in the canonical proceedings, nullity of marriage, Archdiocesan Metropolitan Court in Bialystok.

The Metropolitan Court in Bialystok was erected as the Archbishop Court in Bialystok on the basis of the decree of Metropolitan Archbishop of Vilnius Romuald Jalbrzykowski on 1 September 1945. After the establishment of the Diocese of Bialystok from 6 May 1991 for a period of one year it functioned as the court of bishops. After the 
founding of the Metropolis of Bialystok on 25 March 1992 it became the Metropolitan Court of Bialystok.

The first court official after the war was Fr. Wladyslaw Suszyński, who held this function until 1968. He was succeeded by Fr. Lucjan Namiot. Fr. Andrzej Kakareko held the function of the court official from 23 June 2000. Fr. Tomasz Gierałtowski has held the office of the judicial vicar since 1 September 2008.

Over the years, the court employed many priests who have signed up in the history of the Archdiocese. I would like to mention here two of them. The first one is blessed Fr. Michał Sopocko, who held the office of the Defender of the Marriage Bond. Another one is the recently died Fr. Prelate Stanislaw Strzelecki, who has worked as a judge in the Court for 49 years. I hoped it would be given to us to celebrate fifty years of his work and announce widely that he was a priest probably working in the court as a judge the longest in the world. Well, Our Lord previously called him to give him well-deserved rest.

Over the years the court may notice an increase in the number of cases brought for consideration. First of all, there are the issues to examine whether the marriage was validly solemnized. In this regard, eg. from 1997 to 2003 the average number was 38 cases, and during the years 2004-2012 approximately 70 per year. The upward trend continues, because considering the data for the years 2013-2015 the average was 97 initiated proceedings ${ }^{1}$.

This upward trend persists throughout the country, although the rate of growth in our court against other ecclesiastical courts in Poland is significant. The representatives of the Supreme Tribunal of the Apostolic Signatura, the institution that, among others, collects statistical data about the activities of courts around the world, signaled this tendency. It is not only the result of the increasing number of divorces on the forum of the civil law. Considering that many current cases relate to the couples that got divorced on the forum of civil law many years ago, it is believed that this is also the result of a growing awareness among the faithful that they can turn to the court to investigate their case. There is also of importance the pastoral work of priests who help the people who survived the trauma of relationship breakdown, among other things, when they see the basis, they add them courage to face with the truth about their relationship. This issue is also louder raised in the media. There are a lot of positive fruits of media publicity - a lot of people who normally are little interested in matters of faith,

1 All figures are based on internal documents of the court. 
can learn about the procedure. Nevertheless, media sensationalism brings a lot of confusion in the minds of the audience.

One of the basic problems of communication in terms of these proceedings is a matter of practice commonly used to identify the name of "church divorce". When it is noted that this is the wrong term, the speakers exchange the term with "the cancellation of the marriage", which is also a mistake. What is this proceeding about and how the court really considers these proceedings? There is the need for a few words of explanation.

In the Bible it can be read: "For this reason a man will leave his father and mother and be united to his wife, and the two will become one flesh.' So they are no longer two, but one flesh. Therefore what God has joined together, let no one separate" (Mk 10,7-9). Thus the Church cannot solve the validly solemnized marriage. It cannot follow the practice of the civil courts, which grant divorces. There is only a possibility to consider a situation where the marriage ceremony took place in the church, but in fact the sacrament, and thus marriage for some special, serious reasons did not exist. Then the court does not grant a divorce, but it finds that the marriage did not exist from the beginning, and therefore these people are unmarried.

The Church considering matters relating to the validity of the sacraments is guided by its special law - the canon law. Only on the basis of this law may be declared that the marriage is invalid ${ }^{2}$. Code of Canon Law says: "Marriage possesses the favor of law; therefore, in a case of doubt, the validity of a marriage must be upheld until the contrary is proven" 3 . If the marriage is considered to be valid, it is also existing for God, even when in the reality of everyday life spouses do not live together anymore, and are even in relation with other people.

The ecclesiastical court focuses on the wedding, so at this moment, when marriage is constituted. It is thus clear that the focal point of the proceedings in the ecclesiastical court is completely different from that which is emphasized in divorce proceedings at the forum of secular law, where the attention is focused on the current situation of the couple. People hearing about the "church divorce" almost automatically try to transfer the experience of divorce proceedings at the forum of the ecclesiastical court being focused in the petitions, statements almost exclusively on the events that ultimately led to the parting of applicants. Sometimes, even not occasionally, judges are

2 Pope Francis, Apostolic letter motu proprio „Mitis Iudex Dominus Iezus” (hereinafter MI). Can. $1671 \S 1$.

3 Code of Canon Law (hereinafter CIC). Can. 1060. 
simply inundated with information about the breakup of a relationship, and despite the efforts they are not able to get properly comprehensive knowledge about the origin of a particular couple, the pre-marriage history, the decisions to marry or the environment from which they grew out. I often read volumes of acts, which in total did not include the relevant data to prove the nullity of the marriage with the required moral certainty ${ }^{4}$. In some cases, just getting a negative judgment results in a kind of awakening, which ultimately allows in the appeal to focus on the crux of the problem and thereby get the opportunity to stand in the truth about the validity of the marriage. Thus, often only an appeal enables judges to have a chance to get a moral certainty as to the invalidity of the marriage.

Canon law

There is a need to wean from the use, even in everyday life, of the so-called mental shortcut of "church divorce". This raises also the postulate that people who are aware of it should care to eliminate this term from the media.

The lack of awareness concerning the procedure of the invalidity of marriage makes it increases the number of cases that are negative and states that do not proved the nullity of the appealed marriage. We deal with the issues that have been accepted for proceeding. Many of the cases where it is clear that in a given case there is no reason to believe to be able to prove that the marriage is null, are eliminated at the stage of preliminary discussions ${ }^{5}$. Considering the Court of First Instance, in the years $1997-2003$ the negative cases were $10.57 \%$ of the total number. This indicator increased to $18.6 \%$ from 2004 to 2012 to reach $20 \%$ recently $^{6}$.

Another factor of the growth of negative judgments is also a discrepancy in the attitudes of the concerned people. In addition to people who feel the lack of the possibility to perform to the Sacrament of Reconciliation and Holy Communion, because after the collapse of the appealed marriage they live in another, though not necessarily formalized relationship, but there are also people for whom the lack of participation in these sacraments do not matter. These people do not apply to the court, which sometimes makes it impossible to obtain a moral certainty when deciding the case.

$4 \quad$ Pontifical Council for Legislative Texts, Instruction to be observed by diocesan and interdiocesan tribunals in handling causes of the nullity of marriage Dignitas connubii (hereinafter DC). Art. 247; See The rules of procedure in cases of nullity of marriage - attachment to MI (hereinafter ZP), art. 12; can. 1608. Cf. can. $1505 \S 2$ n. 4 CIC; see. ZP art. $2-5$. 
On the other side, unfortunately, quite a common reason for not appearing in the court is also a lack of understanding in the interpretation of submitted by the court correspondence. The other person ${ }^{7}$ should be notified about the petition in the court and under strictness of nullity of court proceedings ${ }^{8}$. The letter includes a copy of a court petition ${ }^{9}$. It happens many times that the recipient assumes that the author of the statement of claim is the court, or that the court supports the thesis contained in the petition and favours him. The court if a lawsuit is formally correct, is obliged to initiate proceedings. In contrast, judges acknowledge the content of the lawsuit and they will be issuing a verdict. It is the procedure that allows to gather evidence to be able to judge. How difficult is it to pass the information to the defendant, when he gives up at all with the possibility of contact with the court, or full of sorrow and sometimes anger does not allow to dialogue, when, calling for the court, pour a stream of words, often threatening to notice the Prosecutor's Office in their view, about the slander by the court.

The same applies to the naming of a person as a defendant. It is almost automatically equated mistakenly, as the person accused. There are many people who have misread the explanation that this definition is purely technical and that both sides have virtually the same rights and obligations and full of emotions call to the court.

Unfortunately, more and more often in the situations described above, the respondents do not want to hear explanations and give up participation in the proceedings ${ }^{10}$. It hurts that they do not want to understand that the court depends on the fact that the image of their relationship will not be falsified, as when the one-sided exposure of the case can happen even with full goodwill of all ${ }^{11}$.

The court is seeking to make the most objective presentation of the case, so it is important to be able to collect as much relevant information on the matter as it is possible. It is the very unpleasant fact that more and more people designated by the sides as the witnesses refused to appear in the court. It should be emphasized that the refusal to testify significantly hinders the conduct of the proceedings and can have a significant impact on the final judgment. The attitude like "I know little on the subject, or I do not want to get involved in this" does not

$7 \quad$ Can. 1507 \& 1 CIC; art. 126 \& 1 DC.

8 Can. 1511 CIC, art. 128 DC.

9 See 1508 \& 2 CIC; art. $127 \S 3$ DC.

10 Cf. can. 1476 CIC; see. art. 95 DC.

11 Cf. can. 1592 § 1 CIC; art. 138 § 1 DC. 
unload a person from the result of the proceedings. The court shall assess the importance of evidence ${ }^{12}$. Quite often witnesses are not able to assess the seriousness of their information. The reluctance to talk about someone also does not relieve the conscience of a person from helping the Church to explain the resulting major doubts. The point is about the good of the sacrament. Ignoring the request of the applicant to be a witness in the case and the fact of being subpoena, a person should be aware that he takes in conscience full responsibility for any damage, which because of this will result not only for those interested in the proceedings, but for the entire Church, which cares about the validity and dignity of the sacraments.

The court would facilitate the participants in the proceedings the opportunity to testify. A person, if the court conducting the proceedings was earlier informed, does not have to appear for the hearing at the headquarters of the court. Such a hearing at the request of the court conducting the matter, may be conducted in the nearest place of residence of the person. Sometimes, if the situation requires, a representative of the Catholic mission, and even the parish priest conducts such hearings ${ }^{13}$.

Another problem is the sincerity of the testimony ${ }^{14}$. Some witnesses probably think that if they have been identified by one side, so they may not speak badly about this person. In general, they do not take into account that they should testify the truth. It happens that a person of the proceedings even admits to the mistakes, describes in detail the improper behavior, even there is the evidence of the fact that the events took place and the witness participated in them, and a witness of these events even denies that such facts had occurred.

These are just some of the problems faced by judges leading the case for nullity of marriage. I introduced these, which I think are now the most important. Difficulties will always exist, and saying defiantly judges are appointed to solve them.

Although there are many cases, however, there is the need to encourage people who have undergone the trauma of marital breakdown to face with getting to know the truth about their relationship. Each of the spouses can petition the court for nullity of marriage ${ }^{15}$. The court should be one of the following: 1) the court of the place (the diocese), in which the marriage was solemnized; 2) a domicile or quasi-domicile

\footnotetext{
12 See can. 1572 CIC; art. 201 DC.

$13 \quad$ Can. 1418; ZP art. 7 § 2.

14 Cf. can. 1548 \$ 1 CIC; art. $194 \S 1$ DC.

$15 \quad$ Can. $1674 \S 1 \mathrm{MI}$.
} 
within the territory of the court by at least one of the spouse ${ }^{16} ; 3$ ) the tribunal of the place where people have to collect most of the evidence ${ }^{17}$.

However, the judge before accepting the case should be sure that the marriage broke up in an irreversible manner, so that there is no possibility of the resumption of the community of married life ${ }^{18}$. There is the need to avoid such situations, that the individuals demand to have information from the judge on the first interview asking for the declaration that their marriage will be considered null. At the same time, they state that such a declaration would be the determining factor to start their divorce proceedings in the civil court. There is the need of great pastoral sense. It should be always considered seeking professional help in solving marital crisis, even in family counseling centers. On the other hand, when the situation is critical, a person should remember about not being called to heroic "martyrdom" in a sick relationship and has the right to part with the ties of "roof, table and bed". Sometimes it is necessary to protect the self, children, and even the other side from the possibility of coming to some kind of tragedy. Sometimes the determined attitude of a spouse can lead to repentance of the other person and begin the process of healing the relationship. The case will not be taken into consideration by the ecclesiastical court before on the forum of secular law the breakdown of the relationship is not confirmed ${ }^{19}$. However, the fact of the divorce does not prejudge the outcome of the proceedings in the ecclesiastical court.

A lot of emotions awaken also information on the abbreviated process of marriage ${ }^{20}$. Many people, citing the media, even today demand that their case should be resolved within a month. It is of importance, that the cases in the tribunal are considered in the order of their receipt $^{21}$. Upon receipt of the case it shall be directed to the official, who

Place of residence shall be construed in accordance with can. 102 CIC and should not be confused with the registered place.

17 Can 1672 MI. It is a novelty because until the taking effect of the "Mitis Iudex Dominus Iesus" - December 8, 2015 the competent court was the court from n. 1 and the court of residence of the defendant. Two further bases (the place of residence of the defendant and n. 3 ) could be considered only if there is consent of the official from the place of residence of the defendant. The principle of proximity between the judge and the spouses should also be in use as far as possible, see. ZP art. $7 \S 1$.

18 Can. 1675 MI.

19 See. ibid.

20 Art. 5 MI.

21 Can. 1458 CIC. 
in preliminary proceedings decides which mode is to proceed ${ }^{22}$. Only when he decides to direct the case to the shortened procedure, the terms run quickly and it is hoped that practically within approximately 2 months from this moment the proceedings will be terminated, unless the diocesan Bishop has received the required moral certainty as to the nullity of the marriage, which results in the transfer of the case to the regular mode ${ }^{23}$. To be able to consider the possibility of the shorter procedure, the case should be filed by both spouses, or with the consent of the other ${ }^{24}$. Here it must be remembered that both spouses are to be consistent about the wish to annul their marriage, but also agree on the title, which is the basis for such a case. There may not be even a situation that although the two sides talk about the simulation of marriage, however, the plaintiff says on the simulation of the defendant, and the defendant on the simulation of the plaintiff. Moreover, these facts and circumstances do not require more research and investigation, and clearly indicate nullity ${ }^{25}$. It should be noted that quite often obvious things cannot be directed to the shorter procedure because the defendant refuses to take part in the proceedings. On the other hand, it is sometimes difficult to explain to the persons that, although the report together and together indicate a title that can be raised in the proceedings, the matter in the light of the law, is not as obvious as they seem ${ }^{26}$.

22

Can. 1676 MI.

The session should be completed within 30 days - can. 1685 MI. Then the persons have 15 days to submit their comments and appeals - can. $1686 \mathrm{MI}$. It should be added the time for transmission of the letters by the post. Then the diocesan bishop must have time to consult with the instructor and the assessor, to consider the case, make a decision and write the judgment - can. $1687 \mathrm{MI}$.

24 Can. 1683 n. 1 MI.

See can. 1683 n. 2 i 1684 MI.

There are many misunderstandings due to the misinterpretation of art. $14 \S$ 1: "Among the circumstances of things and persons that can allow a case for nullity of marriage to be handled by means of the briefer process according to cann. 1683-1687, are included, for example: the defect of faith which can generate simulation of consent or error that determines the will; a brief conjugal cohabitation; an abortion procured to avoid procreation; an obstinate persistence in an extraconjugal relationship at the time of the wedding or immediately following it; the deceitful concealment of sterility, or grave contagious illness, or children from a previous relationship, or incarcerations; a cause of marriage completely extraneous to married life, or consisting of the unexpected pregnancy of the woman, physical violence inflicted to extort consent, the defect of the use of reason which is proved by medical documents, etc". Please note that the substantive law was not changed and the above set of cases is only a list of examples. Each case is considered individually. 
A special motive of not submitting a case in the ecclesiastical court is also a belief of the enormous costs of the proceedings. The applicant obviously should defray the expenses. This is due to justice. The fee depends on the court, each one of them autonomously calculates them, but I assure that they are at a level that can be covered by and average earning person. Moreover, in a situation of shortage of finance, a person can apply for a reduction of fees, and even total exemption. There is also the possibility to ask for payment in installments. In our court the installment fees are not charged in the form of interest or commissions. The point is that a person cannot be deprived of care of ecclesiastical court because of financial shortfalls. However, the decision to grant free legal assistance belongs to the ecclesiastical judge, who examines each case individually. It is about people who are in fact not only subjectively, in a difficult financial situation ${ }^{27}$.

The most important is the spiritual good of the faithful ${ }^{28}$. Therefore, there is a need that a man who needs help of the ecclesiastical court went there without unnecessary procrastination. I do not recommend to use the assistance of the contingent advisers, especially on the internet. It happens that there are the scammers who extort large amounts for their dubious services. People should seek information at the source, ie in the nearest ecclesiastical court. There clients can also get information about lawyers who have permission to work in this kind of the court.

At the same time, it is expected that the petitioner presents his case as honestly as it is possible. That is expected also of all participants in the proceedings. The increasing number of cases makes the expectancy for the judgment is longer. Well, people have to be patient. However, the faster the case will be presented to the court, the faster the court will be able to consider it.

As the official, I can assure everyone that no one in the ecclesiastical court does not depend on the extension of proceedings. Metropolitan Court in Bialystok, like every institution can and has its organizational stumble, but we do what we can to best serve the petitioners.

$27 \quad$ See Can. 1649.

28 See Can. 1752 CIC 


\section{SŁÓW KILKA O TRUDNOŚCIACH W POSTĘPOWANIU O STWIERDZENIE NIEWAŻNOŚCI ZAWARCIA ZWIĄZKU MAŁŻEŃSKIEGO I SĄDZIE METROPOLITALNYM BIAŁOSTOCKIM}

Autor artykułu po krótkiej refleksji przypominającej historię Sądu Metropolitalnego w Białymstoku porusza zagadnienia dotyczące samego postępowania kanonicznego. Zwraca uwagę na funkcjonujące w powszechnej świadomości społecznej, a szczególnie w środkach przekazu pojęcie „rozwód kościelny". Wykazuje jak błędne jest to sformułowanie i jakie negatywne skutki pociąga za sobą jego używanie. Prowadzi to bowiem do utożsamiania kanonicznego postępowania o stwierdzenie nieważności zawarcia małżeństwa z postępowaniem rozwodowym. Podobnie autor wyjaśnia kim jest strona pozwana w procesie kanonicznym, tak często błędnie utożsamiana w powszechnym rozumieniu z oskarżonym w procesie karnym. Ponadto wskazuje jak ważną rolę w postępowaniu odgrywa świadek. Autor przestrzega zainteresowanych postępowaniem kanonicznym przed korzystaniem z przypadkowych porad prawnych i zachęca te osoby do bezpośredniego kontaktu z sądami kościelnymi, gdzie można znaleźć życzliwą i fachową poradę prawną.

Słowa kluczowe: proces kanoniczny, strony w postępowaniu kanonicznym, świadek w postępowaniu kanonicznym, stwierdzenie nieważności, Archidiecezjalny Sąd Metropolitalny w Białymstoku.

\section{Bibliography:}

1. Code of Canon Law.

2. Francis, Apostolic letter motu proprio „Mitis Iudex Dominus Iesus”.

3. Pontifical Council for Legislative Texts, Instruction to be observed by diocesan and interdiocesan tribunals in handling causes of the nullity of marriage Dignitas connubi

4. The rules of procedure in cases of nullity of marriage - attachment to Mitis Iudex Dominus Iesus. 